\title{
Diagnostic Challenges Arising from Neuropsychiatric Manifestations of Syphilis: Insights from 11 Clinical Cases
}

Diana Maria BRAN' ${ }^{1}$, Amalia GHERGU' ${ }^{1}$, Irene DAVIDESCU ${ }^{1,2}$

\begin{abstract}
Over the past 70 years, the incidence of syphilis has dramatically decreased and consequently the neurosyphilis one. Therefore, when a patient is presented with neuropsychiatric symptoms such as psychosis, mania, memory loss, neurocognitive troubles, attention deficits, behavioral changes, or depression, a neurosyphilis diagnosis is not the first that comes to a clinician's mind. In fact, many times, patients are first treated with psychiatric medication when penicillin would be the appropriate line of treatment. In this article, after we review neurosyphilis, we report 11 clinical cases with neuropsychiatric manifestations of syphilis and make the case for careful syphilis screening in patients presenting with psychiatric and neurological symptoms.
\end{abstract}

Keywords: neurosyphilis, screening, neuropsychiatric manifestations.

\section{Rezumat}

Incidența sifilisului a scăzut dramatic în ultimii 70 de ani, iar ca urmare și cea neurosifilisului. Din acest motiv, atunci când un pacient se prezintă pentru diverse manifestări neuropsihiatrice, precum psihoză, manie, tulburări amnestice, neurocognitive, deficite de atenție, modificări de comportament, depresie, diagnosticul de neurosifilis nu este primul evocat. Într-adevăr, se întâmplă frecvent ca pacienții cu neurosifilis să fie tratați inițial cu medicație psihiatrică, deși tratamentul adecvat este cel antibiotic cu penicilină. În acest articol, după o prezentare generală a acestei patologii, prezentăm o serie de 11 cazuri clinice de pacienți diagnosticati cu sifilis în stadiu terțiar, care s-au prezentat cu manifestări neuropsihiatrice și argumentăm de ce se justifică un screening de Treponema pallidum la pacienții cu acest tip de simptome.

Cuvinte cheie: neurosifilis, screening, manifestări neuropsihiatrice.

\section{INTRODUCTION}

Once called „The Great Masquerader”, syphilis remains, to this day, hard to diagnose. This article specifically refers to the challenge posed by neurosyphilis to psychiatrists and neurologists alike.

Syphilis is caused by Treponema pallidum. After the introduction of penicillin, the prevalence of syphilis has dramatically decreased. However, after the 1990's there has been a resurgence of the disease in Europe, possibly explained by the HIV outbreak ${ }^{1}$. In Romania, the incidence of syphilis was estimated by one epidemiological study to be around 25 cases per 100.000 inhabitants $^{2}$.

\section{Syphilis from a neuropsychiatric perspective}

There are several stages of syphilis: early, secondary, latent and tertiary syphilis. If untreated, up to $30 \%$ of patients can develop tertiary syphilis which may pre-

\footnotetext{
1 Department of Neurology, Colentina Clinical Hospital, Bucharest, Romania

2 "Carol Davila" University of Medicine and Pharmacy, Bucharest, Romania
}

\section{Corresponding author.}

Irene Davidescu, $2^{\text {nd }}$ Department of Neurology, "Carol Davila" University of Medicine and Pharmacy, Colentina Clinical Hospital, Bucharest, Romania.

E-mail: eugenia.davidescu@umfcd.ro 
sent as cardiovascular disease, gummas or neurosyphilis $^{3}$. Treponema pallidum invades the central nervous system starting with the meninges, the patients developing either aseptic meningitis or meningovascular syphilis. Usually, the meningitis persists asymptomatically for years, before leading to parenchymal lesions. During this late stage, neurosyphilis can manifest itself as several different clinical syndromes: general paresis, tabes dorsalis, subacute myelitis or optic nerve atrophy ${ }^{3}$.

From a neuropsychiatric perspective, neurosyphilis is extremely heterogenous. Indeed, it can take many different forms, patients presenting, with a combination of the following: psychosis, mania, memory loss, rapidly progressive dementia, early onset dementia, fronto-temporal dementia, attention deficits, behavioral changes, aggressive behavior, depression, confusion, visual or auditory hallucinations, dysarthria, myoclonus, intentional tremor, seizures, strokes, personality disorders, delirium, disruption of the sleep-wakecycle, urinary incontinence, dysphoria ${ }^{4}$. Neurosyphilis can indeed imitate almost all neuropsychiatric disorders.

There are many case reports that underline the fact that appropriate treatment may be delayed due to nonspecific psychiatric symptoms. For instance, Costiniuk and MacPherson eported 3 patients who presented with sleep disturbances, psychosis, hyperactivity, seizures, cognitive impairment, lower-limb weakness and dysarthria ${ }^{5,6}$.

This pleomorphic character, together with the low incidence of neurosyphilis, poses serious diagnostic challenges to psychiatrists and neurologists alike. Indeed, patients are sometimes diagnosed with neuropsychiatric disorders and subsequently treated with psychiatric medication (memantine, donepezil, risperidone, olanzapine and others) when in fact the treatment of choice should be the same old penicillin.

This is why screening for neurosyphilis is warranted in patients presenting both typical and atypical psychiatric symptoms.

Screening for syphilis is achieved using serum nontreponemal tests such as VDRL (Veneral Disease Research Lahoratory). The next step is to confirm the syphilis diagnosis with a serum treponemal test such TPHA (Treponema Pallidum Haemagglutination Assay), TPPA (Treponema pallidum Particle Agglutination Test), RPR (reagin plasma response) or the FTA-abs test (fluorescent treponemal antibody absorption). Further on, a third necessary step to diagnose neurosyphilis is to perform a lumbar puncture and cerebrospinal fluid (CSF) examination. This must include total CSF protein, a mononuclear cell count, and both a non-treponemal and treponemal test. An abnormal CSF result is considered to highlight high protein levels and/or pleocytosis, plus a positive treponemal or non-treponemal test ${ }^{7}$.

It is important to remember that only 1 in 3 neurosyphilis patients has a positive CSF VDRL test. Moreover, a positive treponemal test such as TPHA does not confirm the diagnosis of neurosyphilis, but a negative result is highly unlikely in a patient with neurosyphilis. Furthermore, a normal protein level is possible. The lumbar puncture must be repeated 6 weeks to 6 months after treatment ${ }^{7}$.

Due to possible complications of the lumbar puncture, a CSF assessment is not indicated in early syphilis, unless there are neurological, auricular or ocular symptoms. A lumbar puncture is only indicated in patients presenting signs of tertiary syphilis (for instance cardiovascular involvement) or presenting neurological, ocular or auricular symptoms, regardless of stage . $^{7}$.

Once a neurosyphilis diagnosis is made, treatment with benzyl-penicillin intravenous should be promptly initiated. Other second line options include ceftriaxone or procaine penicillin in association with probenecid. The goal of penicillin treatment is to prevent further progression and to possibly reverse symptoms.

Treated early on, neurosyphilis patients have a relatively good prognosis. Patients with early meningeal neurosyphilis have a complete resolution of symptoms. However, for late stage neurosyphilis, with constituted parenchymal lesions, the prognosis is highly variable and symptoms may persist. Currently, there is no evidence-based recommendation regarding further treatment with psychiatric medication and this should be carefully decided for each individual patient ${ }^{8}$.

\section{CLINICAL CASES}

\section{Methods}

The medical records of eleven patients diagnosed with neurosyphilis at Colentina Clinical Hospital and Alexandru Obregia Clinical Hospital of Psychiatry were reviewed. Patients included in this study were diagnosed with syphilis by lumbar puncture and CSF analysis.

\section{Results}

The mean age of our patients was 50.36 \pm 9.87 (10 men and 1 woman).

Six of the patients presented with acute symptoms: three had an acute psychotic episode, two patients had 
an acute confusional state and one patient was initially diagnosed with encephalitis and developed psychotic behaviour afterwards. Four patients had a chronic progression of symptoms and had been diagnosed with dementia prior to a syphilis diagnosis. Two of the patients had been previously diagnosed with schizofrenia and personality bipolar disorder. Overall, the clinical onset of symptoms was documented, after taking a careful personal history, to be at a mean period of 2.4 years before the diagnosis. It is worth mentioning that two patients were heavy drinkers, and had signs of Wernicke's encephalopathy, two patients had associated cardiovascular risk factors - diabetes type II, arterial hypertension and atrial fibrillation - and one patient died from complications of bronchopneumonia. From the group of patients diagnosed with dementia, two had beentreated with donepezilum, one had been treated with pramiracetamum and one with memantine prior to their syphilis diagnosis.

In all patients, venereal disease research laboratory (VDRL) and Treponema pallidum Particle Agglutination Test (TPPA) were positive in the blood and afterwards also in CSF. We also performed HIV testing and all patients were negative. All patients denied prior history of syphilis.

\section{DISCUSSIONS}

Generally, most of the patients with neurosyphilis can present with many different physical or neurological symptoms that lead to admission or follow-up at a medical or neurological unit. What is interesting in our

\section{References}

1. Simms I, Fenton KA et al. The re-emergence of syphilis in the United Kingdom: thenew epidemic phases. Sex Transm Dis 2005;32(4):220-6.

2. Neghina $R$ et al. Epidemiology of syphilis, gonorrhea and chlamydia in Romania, 1980-2009. Journal of Infection 2011 Jul; 63(1): 54-59.

3. Friedrich F, Geusau A et al. Psychosis in neurosyphilis. Gen Hosp Psychiatry. 2009 Jul-Aug;31(4):379-81.

4. Lin LR, Zhang HL, Huang SJ, et al. Psychiatric manifestations as primary symptom of neurosyphilis among HIV-negative patients. J Neuropsychiatry Clin Neurosci. 2014;26(3):233-40. cases is that the majority showed exclusively psychiatric manifestations, which led to direct admission to a psychiatric unit.

Patients were treated with penicillin (1.000.000 UI every 4 hours during 3 weeks and afterwards 1.200 .000 UI N.N. dibenzyletilendiamin-dipenicillinum $G$ every week during one month). Most of them needed three treatment cures for achieving great improvement of cognitive troubles. However, behavioral disturbances persisted and 7 patients further required long term neuroleptic and antidepressive therapies.

In our younger patients behavioral disturbances were the most frequent ones, whereas in the older ones, cognitive and memory troubles were the main symptoms.

\section{CONCLUSION}

Special care should be given to patients presenting with neuropsychiatric symptoms and the diagnosis of neurosyphilis, albeit rare, should be always on the clinician's mind. Moreover, a screening for syphilis is cheap and acceptable to the patient, so it should always be considered.

\section{Compliance with ethics requirements:}

The authors declare no conflict of interest regarding this article.

The authors declare that all the procedures and experiments of this study respect the ethical standards in the Helsinki Declaration of 1975, as revised in 2008(5), as well as the national law. Informed consent was obtained from all the patients included in the study.

5. Costiniuk CT, MacPherson PA. Neurocognitive and psychiatric changes as the initial presentation of neurosyphilis. CMAJ. 2013; 185(6):499-503.

6. Crozatti LL, de Brito MH, Lopes BN, de Campos FP. Atypical behavioral and psychiatric symptoms: Neurosyphilis should always be considered. Autops Case Rep. 2015;5(3):43-7. Published 2015 Sep 30. doi:10.4322/acr.2015.021

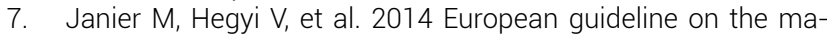
nagement of syphilis. J Eur Acad DermatolVenereol. 2014 Dec; 28(12):1581-93.

8. Ghanem KG. Neurosyphilis: A historical perspective andreview. CNS Neuroscience and Therapeutics. 2010 Oct;16(5). 
